\title{
Effect of pentobarbitone sodium and bromocriptine on follicular oestradiol production in the rat
}

\author{
J. Th. J. Uilenbroek \\ Department of Endocrinology, Growth and Reproduction, Faculty of Medicine, Erasmus University, \\ P.O. Box 1738,3000 DR Rotterdam, The Netherlands
}

\begin{abstract}
Summary. Injection of an ovulation-blocking dose of pentobarbitone sodium given in the early afternoon of pro-oestrus in rats decreased follicular oestradiol production in vitro the next day $(2.42 \pm 0.11 \mathrm{ng} / 4 \mathrm{~h} /$ follicle in pro-oestrous rats, $0.49 \pm 0.04 \mathrm{ng} / 4 \mathrm{~h} /$ follicle in pentobarbitone-treated rats). Pentobarbitone, given 1 day earlier (at dioestrus II), prevented the increase in oestradiol production that normally occurs between di-oestrus II and pro-oestrus. Injection of a subovulatory amount of hCG $(0.5$ i.u.) given after pentobarbitone injection inhibited the decrease in follicular oestradiol production induced by pentobarbitone.

The pentobarbitone-induced decrease in oestradiol production was also prevented by bromocriptine $(1 \mathrm{mg})$ given at di-oestrus II $(15: 00 \mathrm{~h})$ and pro-oestrus (09:00 $\mathrm{h}$ ). Bromocriptine is an effective inhibitor of prolactin secretion and this suggests therefore that the decrease in follicular oestradiol production after pentobarbitone is due to the preovulatory surge of prolactin. However, pretreatment with bromocriptine also inhibited the effect of pentobarbitone on oestradiol production when pentobarbitone was given at di-oestrus II. Moreover, when ergocornine (another inhibitor of prolactin secretion) was used instead of pentobarbitone to block ovulation, follicular oestradiol production was also decreased the next day. In contrast to bromocriptine, ergocornine was not able to prevent the pentobarbitone-induced decrease in follicular oestradiol production.

These results indicate that the decrease in follicular oestradiol production after pentobarbitone injection is due to inhibition of the serum concentrations of $\mathrm{LH}$ rather than the preovulatory surge of prolactin. How bromocriptine (but not ergocornine) prevents the pentobarbitone-induced decrease in oestradiol production is not clear.
\end{abstract}

Keywords: delayed ovulation; pentobarbitone; bromocriptine; preovulatory follicles; oestradiol production; rat

\section{Introduction}

It is known that inhibition of the preovulatory surge of luteinizing hormone ( $\mathrm{LH}$ ) by an injection of pentobarbitone sodium on the early afternoon of pro-oestrus in the rat prevents ovulation and induces atresia of the large preovulatory follicles (Everett \& Sawyer, 1950). This procedure has been used to study temporal changes of preovulatory follicles becoming atretic in rats (Uilenbroek et al., 1980; Braw \& Tsafriri, 1980) and hamsters (Terranova, 1981). The large antral follicles present the day after pro-oestrus produce a low amount of oestradiol in vitro compared to follicles isolated at pro-oestrus (Uilenbroek et al., 1980). This decrease in oestradiol production is due to a decrease in the enzyme activity converting progesterone to androgens, thereby limiting the amount of substrate available for aromatization (Terranova, 1981; Uilenbroek et al., 1984). 
How pentobarbitone causes this decrease in enzyme activity is not known. It has been shown that administration of the dopamine agonist, bromocriptine, delays the pentobarbitone-induced decrease of follicular oestradiol production (van der Schoot et al., 1982) and partly prevents the decline in serum androstenedione (Terranova \& Ascanio, 1982). From these experiments it has been concluded that the decrease in oestradiol secretion might be due to the preovulatory surge of prolactin. This surge is not or only partly blocked by the injection of pentobarbitone (Ayalon et al., 1972). Furthermore, prolactin can have a direct inhibitory effect on oestradiol production of growing follicles (Uilenbroek \& van der Linden, 1984).

It was the aim of the present study to investigate whether the decrease in follicular oestradiol production after pentobarbitone on pro-oestrus is due to the preovulatory surge of prolactin or to a decrease in the circulating concentrations of serum $\mathbf{L H}$.

\section{Materials and Methods}

Animals. Adult female rats, F1 hybrids from two inbred Wistar substrains (R-Amsterdam females and U males), were kept under standard conditions of light (on 05:00-19:00 h) and temperature $\left(20-23^{\circ} \mathrm{C}\right)$. The animals showed nearly exclusively $(>95 \%)$-day reproductive cycles as determined by daily vaginal smears. Animals with regular 4-day reproductive cycles could be obtained in these rats after they experienced pseudopregnancy. Pseudopregnancy was induced by copulation with a vasectomized male. As many as 10 consecutive 4-day cycles could be obtained before the reappearance of 5-day cycles (van der Schoot \& de Greef, 1976).

Treatments. Pentobarbitone sodium (OPG, Rotterdam, The Netherlands) was injected i.p. ( $37 \mathrm{mg} / \mathrm{kg}$ body weight) between 13:00 and 13:30 h on the day of pro-oestrus $(\mathbf{P})$ to prevent ovulation. To prevent delayed ovulation a second injection was given the next day $(P+1)$ between 13:30 and 14:00 h. In one experiment ergocornine (Sandoz, Basel, Switzerland) was used to block ovulation (Nooter \& Zeilmaker, 1970). Ergocornine was injected i.p. in a dose of $1 \mathrm{mg} / \mathrm{rat}$. Bromocriptine (Sandoz, Basel, Switzerland) and ergocornine were dissolved in $96 \%$ ethanol and then diluted with an equal volume of $0.9 \%(\mathrm{w} / \mathrm{v}) \mathrm{NaCl}$. In the experiment in which bromocriptine or ergocornine were given in combination with pentobarbitone, these compounds were injected s.c. in a dose of $1 \mathrm{mg} / 0-2 \mathrm{ml}$. The first injection was given at 15:00 $\mathrm{h}$ on the day of dioestrus II and the second injection was given at 09:00 $\mathrm{h}$ on pro-oestrus. The animals were killed the next day $(P+1)$ between 09:00 and 11:00 h.

In one experiment pentobarbitone was given between 13:00 and 13:30 h on the day before pro-oestrus (di-oestrus II) and bromocriptine treatment was given at di-oestrus I ( $15: 00 \mathrm{~h})$ and di-oestrus II $(09: 00 \mathrm{~h})$. The animals were killed at pro-oestrus between 09:00 and 11:00 h.

When human chorionic gonadotrophin (hCG) was used in combination with pentobarbitone, the hCG (Pregnyl; Organon, Oss, The Netherlands) was dissolved in $0.9 \%(\mathrm{w} / \mathrm{v}) \mathrm{NaCl}$ and given s.c. in a volume of $0.1 \mathrm{ml}$ immediately after the injection of pentobarbitone.

At autopsy the ovaries were dissected and the 10-12 largest follicles were isolated under a dissection microscope.

To detect the effect of various treatments on the concentrations of serum LH and prolactin, blood was collected under light ether anaesthesia by puncturing the ophthalmic venous vessels. Blood was allowed to clot overnight at $4^{\circ} \mathrm{C}$ before centrifugation. Thereafter the serum was separated and stored frozen until assayed.

Follicle incubation. Follicles were incubated individually in $500 \mu \mathrm{l}$ Medium 199 (Grand Island Biological Company, Grand Island, NY, USA) containing 10 mM-Hepes (Sigma Chemical Co., St Louis, MO, USA) at pH 7.4. The incubations were carried out in a shaking water bath at $37^{\circ} \mathrm{C}$ under an atmosphere of $95 \% \mathrm{O}_{2}$ and $5 \% \mathrm{CO}_{2}$. After $4 \mathrm{~h}$ of incubation the follicles were discarded and the medium was stored at $-20^{\circ} \mathrm{C}$ until assayed for steroids.

Hormone measurements. Concentrations of oestradiol- $17 \beta$ and progesterone in the incubation medium were measured by radioimmunoassay without prior extraction as previously described (Uilenbroek et al., 1980). The sensitivity of the oestradiol assay was $10 \mathrm{pg} /$ tube and the inter- and intra-assay variations were $8.3 \%$ and $7 \cdot 2 \%$ respectively. The sensitivity of the progesterone assay was $25 \mathrm{pg} /$ tube and the inter- and intra-assay variations were $8 \cdot 8$ and $9.2 \%$ respectively.

Serum LH and prolactin concentrations were measured by double-antibody radioimmunoassay. Anti-ovine LH serum and iodinated rat LH (NIADDK-rat LH I-3) were used in the LH assay and anti-rat prolactin serum and iodinated rat prolactin (NIADDK-rat Prl I-2) were used in the prolactin assay. Values were expressed in $\mathrm{ng}$ NIADDK-rat LH RP- 1 and NIADDK-rat prolactin RP- $1 / \mathrm{ml}$ respectively. The limit of sensitivity is $1 \mathrm{ng} /$ tube $(5-10 \mathrm{ng} / \mathrm{ml}$ serum).

Statistics. Values are expressed as means \pm s.e.m. Differences between groups were evaluated by using Student's $t$ test. Differences were considered significant if $P$ was $<0.05$. 


\section{Results}

\section{Effect of pentobarbitone on follicular oestradiol production}

Follicles isolated 1 day after an ovulation-blocking dose of pentobarbitone produced a significantly lower amount of oestradiol in vitro than did follicles isolated at pro-oestrus (Table 1, compare Groups 1 and 2). This occurred irrespective of whether the animals had a 5- or 4-day cycle length (Groups 5 and 6), although in 4-day cyclic rats the oestradiol production at Day P +1 was higher than in 5-day cyclic rats (compare Groups 6 and 2). When pentobarbitone was given 1 day earlier (on the afternoon of di-oestrus II), oestradiol production at pro-oestrus was also lower than in untreated pro-oestrous animals (compare Groups 4 and 1).

Table 1. Oestradiol production after $4 \mathrm{~h}$ of incubation by preovulatory follicles isolated from rats with a 4- or 5-day reproductive cycle: pentobarbitone sodium (PB) was given at pro-oestrus $(\mathrm{P})$ or at di-oestrus II (DII) and follicles were isolated 1 day later $(P+1$ and

$P$ respectively)

\begin{tabular}{lcccc}
\hline Group & $\begin{array}{c}\text { Cycle } \\
\text { length } \\
\text { (days) }\end{array}$ & $\begin{array}{c}\text { Day of PB } \\
\text { treatment }\end{array}$ & $\begin{array}{c}\text { Day of } \\
\text { follicle } \\
\text { isolation }\end{array}$ & $\begin{array}{c}\text { Follicular oestradiol } \\
\text { production } \\
\text { (ng/4 h/follicle) }\end{array}$ \\
\hline 1 & 5 & - & $\mathrm{P}$ & $2 \cdot 42 \pm 0 \cdot 11$ \\
2 & 5 & $\mathrm{P}$ & $\mathrm{P}+1$ & $0 \cdot 49 \pm 0 \cdot 04^{*}$ \\
3 & 5 & - & $\mathrm{DII}$ & $1 \cdot 14 \pm 0 \cdot 14^{*}$ \\
4 & 5 & $\mathrm{DII}$ & $\mathrm{P}$ & $1.55 \pm 0 \cdot 25^{*}$ \\
5 & 4 & - & $\mathrm{P}$ & $2 \cdot 87 \pm 0 \cdot 21$ \\
6 & 4 & $\mathrm{P}$ & $\mathrm{P}+1$ & $1.54 \pm 0 \cdot 21 \dagger$ \\
\hline
\end{tabular}

Values are mean \pm s.e.m. for at least 20 follicles ( 5 rats, 4 follicles per rat). ${ }^{*} P<0.05$ compared with Group $1 ; \dagger P<0.05$ compared with Group 5.

\section{Effect of bromocriptine}

The combined treatment of pentobarbitone at pro-oestrus with bromocriptine given at dioestrus II $(15: 00 \mathrm{~h})$ and at pro-oestrus $(09: 00 \mathrm{~h})$ resulted in a higher oestradiol production $(\mathrm{ng} / 4 \mathrm{~h} /$ follicle) the next day $(P+1)$ compared to animals injected with pentobarbitone only $(1 \cdot 72 \pm 0 \cdot 13$ vs $0.34 \pm 0 \cdot 11: P<0.05, \mathrm{~N}=20)$. A single injection of bromocriptine at $09: 00 \mathrm{~h}$ on pro-oestrus appeared ineffective $(0.72 \pm 0.25 \mathrm{ng} / 4 \mathrm{~h} /$ follicle $)$.

When pentobarbitone was given at di-oestrus II, combined treatment with bromocriptine at di-oestrus I $(15: 00 \mathrm{~h})$ and di-oestrus II $(09: 00 \mathrm{~h})$ resulted in a higher oestradiol production at pro-oestrus than after pentobarbitone only $(3.07 \pm 0.31$ vs $1.61 \pm 0.19 \mathrm{ng} / 4 \mathrm{~h} /$ follicle; $P<0.05$, $\mathrm{N}=20$ ). Bomocriptine treatment without pentobarbitone at di-oestrus II was not able to increase oestradiol production $(3.34 \pm 0.23)$ above the level at pro-oestrus $(2.98 \pm 0.34 \mathrm{ng} / 4 \mathrm{~h} / \mathrm{follicle}$, $\mathrm{N}=20$ ).

\section{Effect of pentobarbitone and bromocriptine on serum $L H$ concentrations}

To investigate whether the increase of follicular oestradiol production by bromocriptine was due to an increase in serum LH levels, serum LH concentrations were measured at 14:00, 16:00 and 18:00 h at pro-oestrus and at 09:00 $\mathrm{h}$ at Day $\mathrm{P}+1$ in animals injected with pentobarbitone at prooestrus. Serum LH concentrations between animals treated with and without bromocriptine were not significantly different (Fig. 1). 
In animals in which pentobarbitone was given the day before pro-oestrus and in which bromocriptine treatment was started at 15:00 h on di-oestrus I, serum LH concentrations at 14:00, 16:00, 18:00, 20:00, 22:00 and 24:00 $\mathrm{h}$ at the day before pro-oestrus were not different between pentobarbitone-treated rats, rats treated with bromocriptine plus pentobarbitone and untreated rats (data not shown).

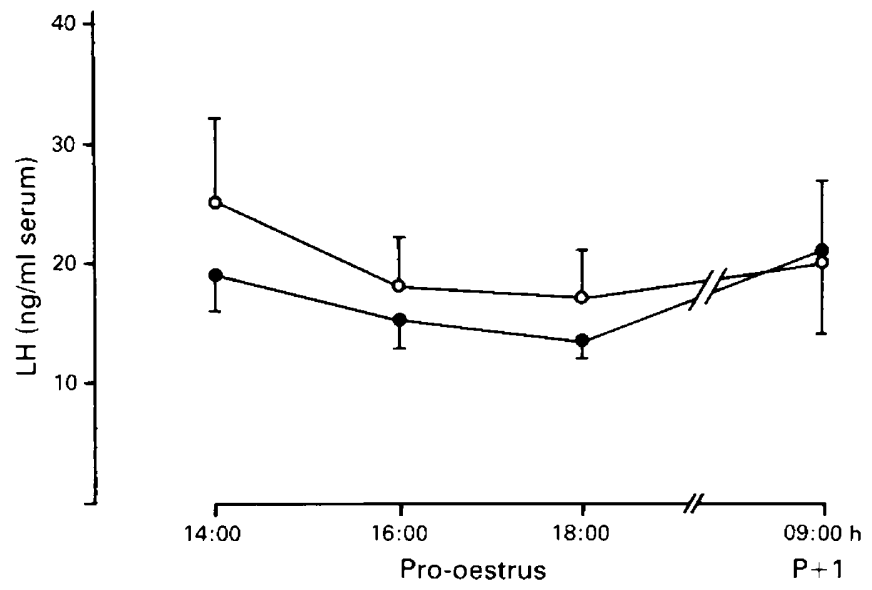

Fig. 1. Serum LH concentrations (mean \pm s.e.m.) at pro-oestrus and the next day in rats treated with bromocriptine $(1 \mathrm{mg})$ at dioestrus $(15: 00 \mathrm{~h})$ and pro-oestrus $(09: 00 \mathrm{~h})$ or vehicle. Bromocriptine-treated $(O)(\mathrm{N}=9)$ and control $(O)(\mathrm{N}=7)$ animals were given an intraperitoneal injection of pentobarbitone sodium at 13:00 h to block the preovulatory LH surge.

\section{Effect of ergocornine}

An injection of ergocornine given in the early afternoon of pro-oestrus was as effective as pentobarbitone in blocking ovulation. The follicles isolated the next day produced a low amount of oestradiol in vitro (Table 2). Serum prolactin concentrations measured at 17:00 h on pro-oestrus were significantly lower in the ergocornine-treated rats than in pentobarbitone-treated rats (Table 2).

Table 2. Effect of pentobarbitone and ergocornine given at prooestrus $(\mathrm{P})$ on serum prolactin concentrations at pro-oestrus $(17: 00 \mathrm{~h})$ and follicular oestradiol production the next day $(\mathrm{P}+1)$

\begin{tabular}{lcccc}
\hline $\begin{array}{l}\text { Treatment at } \\
\mathrm{P}(13: 00 \mathrm{~h})\end{array}$ & $\begin{array}{c}\text { No. of } \\
\text { rats }\end{array}$ & $\begin{array}{c}\text { Day of } \\
\text { follicle } \\
\text { isolation }\end{array}$ & $\begin{array}{c}\text { Prolactin } \\
(\mathrm{ng} / \mathrm{ml})\end{array}$ & $\begin{array}{c}\text { Follicular oestradiol } \\
\text { production } \\
(\mathrm{ng} / 4 \mathrm{~h} / \text { follicle })\end{array}$ \\
\hline Pentobarbitone & 8 & $\mathrm{P}$ & - & $2.52 \pm 0.12$ \\
Ergocornine & 6 & $\mathrm{P}+1$ & $369 \pm 32$ & $0.49 \pm 0.07^{*}$ \\
\hline
\end{tabular}

Values are mean \pm s.e.m. for at least 6 follicles per rat.

$* P<0.05$ compared with untreated rats; $\nmid P<0.05$ compared with pentobarbitone-treated rats. 
The combined treatment of pentobarbitone at pro-oestrus with ergocornine given at di-oestrus II $(15: 00 \mathrm{~h})$ and pro-oestrus $(09: 00 \mathrm{~h})$ resulted in an oestradiol production $(\mathrm{ng} / 4 \mathrm{~h} / \mathrm{follicle})$ not different from that after pentobarbitone alone $(0.57 \pm 0.14 v s 0.81 \pm 0.23)$, while the value for pentobarbitone + bromocriptine treatment was increased $(1.88 \pm 0.40 ; P<0.05 ; \mathrm{N}=30)$.

\section{Effect of $h C G$}

An injection of a subovulatory amount of hCG, given after the injection of pentobarbitone at pro-oestrus, resulted in a dose-dependent increase of follicular oestradiol production the next day (Table 3). The dose of 1 i.u. hCG increased oestradiol production above that found in follicles isolated at pro-oestrus (compare Group 4, Table 3 with Group 1, Table 1). Progesterone production was not increased, indicating that luteinization had not occurred.

A second injection of pentobarbitone at Day $\mathbf{P}+1$ in animals pretreated with pentobarbitone and 0.5 i.u. hCG at pro-oestrus resulted in a decreased oestradiol production at Day $\mathbf{P}+2$ compared to the previous day $(P+1)$ (compare Groups 5 and 3 ). When the second pentobarbitone injection at Day $\mathrm{P}+1$ was followed by a second injection of $0.5 \mathrm{i} . \mathrm{u}$. hCG, follicular oestradiol production at Day $\mathbf{P}+2$ was further increased (compare Groups 6 and 5).

Table 3. Effect of hCG together with an ovulation blocking dose of pentobarbitone $(\mathrm{PB})$ on production of steroids by follicles isolated $1(\mathrm{P}+1)$ or $2(\mathrm{P}+2)$ days after pentobarbitone

\begin{tabular}{|c|c|c|c|c|}
\hline \multirow[b]{2}{*}{ Group } & \multicolumn{2}{|c|}{ Treatment at: } & \multicolumn{2}{|c|}{$\begin{array}{l}\text { Follicular production } \\
\text { (ng/4 h/follicle) }\end{array}$} \\
\hline & Pro-oestrus (P) & $P+1$ & Oestradiol & Progesterone \\
\hline & & & \multicolumn{2}{|c|}{ At Day $P+1$} \\
\hline 1 & PB & - & $0.75 \pm 0 \cdot 18$ & $0.77 \pm 0.17$ \\
\hline 2 & PB +0.1 i.u. hCG & - & $0.93 \pm 0 \cdot 13$ & $0.56 \pm 0.05$ \\
\hline 3 & $P B+0.5$ i.u. hCG & - & $2.83 \pm 0.15^{*}$ & $0.56 \pm 0.08$ \\
\hline 4 & $\mathrm{~PB}+1 \cdot 0$ i.u. hCG & - & $5 \cdot 61 \pm 0.29^{*}$ & $0.76 \pm 0.30$ \\
\hline & & & \multicolumn{2}{|c|}{ At Day $P+2$} \\
\hline 5 & $\mathrm{~PB}+0.5$ i.u. hCG & PB & $1 \cdot 61 \pm 0.15$ & $0.57 \pm 0.08$ \\
\hline 6 & $\mathrm{~PB}+0.5$ i.u. hCG & $\mathrm{PB}+0.5$ i.u. hCG & $4.02 \pm 0.46 \dagger$ & $0.36 \pm 0.03$ \\
\hline
\end{tabular}

Values are mean \pm s.e.m. for at least 24 follicles $(6$ rats, 4 follicles/rat $)$.

${ }^{*} P<0.05$ compared with Group $1 ; \uparrow P<0.05$ compared with Group 5.

\section{Discussion}

The present results show that administration of a subovulatory amount of hCG could overcome the decline in oestradiol production by preovulatory follicles after an injection of pentobarbitone at pro-oestrus, suggesting that this decline is due to a temporary inhibition of the circulating concentrations of LH during pro-oestrus by pentobarbitone. Direct evidence for a lack of LH as the cause of oestradiol decline would have been a decrease in serum LH values after pentobarbitone injection. The inhibitory effect of pentobarbitone on the preovulatory LH surge is well known. However, an effect on the basal LH secretion on the afternoon of pro-oestrus is difficult to assess because of the lack of an appropriate control. Therefore LH concentrations were measured after pentobarbitone administration on the day before pro-oestrus. Failure to find a decrease in serum LH values after pentobarbitone injection might have been due to the fact that at this stage of the cycle the LH concentrations are near the levels of sensitivity of the assay system. Sequential sampling of individual animals and a more sensitive assay are needed to detect possible changes. 
From previous studies it is known that the decrease in follicular oestradiol production after pentobarbitone is due to a decrease in the 17 $\alpha$-hydroxylase/C17-20 lyase complex (Terranova, 1981; Uilenbroek et al., 1984). The present study shows that low, subovulatory amounts of hCG can prevent the decrease of this enzyme complex. This is in agreement with the observation that in growing follicles the activity of this enzyme system is regulated by LH (Bogovich \& Richards, 1982).

Another factor that might be of importance to explain the decrease in follicular oestradiol production after pentobarbitone is the age of the follicle. It has been suggested that the decrease in follicular oestradiol production after pentobarbitone reflects an inherent change in steroidogenesis (van der Schoot, 1980). In 5-day cyclic rats blood concentrations of oestradiol decreased earlier after injection of pentobarbitone at pro-oestrus than in 4-day cyclic rats. Accordingly in the present study in-vitro oestradiol production on the day after pentobarbitone was higher in 4-day than in 5day cyclic rats. It has been suggested therefore that preovulatory follicles at pro-oestrus in 5-day cyclic rats are 1 day older than at pro-oestrus in 4-day cyclic rats (van der Schoot, 1980). So in addition to a lack of $\mathrm{LH}$, the degree of follicular development may also play a role in the decrease of follicular oestradiol production after pentobarbitone sodium injection.

The observation that injection of bromocriptine delays the pentobarbitone-induced decrease in oestradiol production suggests that the surge of prolactin on the afternoon of pro-oestrus might inhibit oestradiol production by ovarian follicles. Several studies have shown that an injection of pentobarbitone at pro-oestrus is ineffective (Ayalon et al., 1972) or only partly effective (Wuttke \& Meites, 1970; Butcher et al., 1975) in decreasing the preovulatory surge of prolactin. An inhibitory effect of prolactin on follicular oestradiol production in vivo has been demonstrated (Uilenbroek \& van der Linden, 1984), and Tsai-Morris \& Johnson (1982) have shown that prolactin can prevent the increase of $17 \alpha$-hydroxylase induced by PMSG. Although a possible effect of prolactin cannot be excluded, it does not explain why an ovulation-blocking dose of ergocornine also results in a low oestradiol production the next day (Table 2), because prolactin concentrations in ergocorninetreated rats are low. It also does not explain why bromocriptine prevents the decrease of oestradiol production induced by pentobarbitone on the day before pro-oestrus, because no surge of prolactin has been reported at that time. It is therefore likely that bromocriptine counteracts the effect of pentobarbitone by a mechanism other than by inhibiting serum prolactin concentrations. However, a stimulatory effect of bromocriptine on serum $\mathrm{LH}$ concentrations has not been found. In contrast, Seki et al. (1974) and Shaban \& Terranova (1986) found a reduction of the basal secretion of LH by bromocriptine. Such an effect on LH explains also why ergocornine does not prevent the pentobarbitone-induced decrease in oestradiol production because ergocornine is much more potent than bromocriptine in inhibiting LH secretion (Flückiger et al., 1976). At present one can only speculate on the possible mechanism whereby the dopamine agonist, bromocriptine, prevents the pentobarbitone-induced decrease in follicular oestradiol production. Since dopamine receptors are not only present in the central nervous system, but also in vascular beds, injection of bromocriptine causes vasodilatation and an increase in peripheral blood flow (Clark et al., 1978). For hamster ovaries, Krishna et al. (1986) demonstrated that an increase in ovarian blood flow stimulates follicular activity by allowing more $\mathrm{LH}$ to reach the ovary.

The results of the present study demonstrate that the decrease in follicular oestradiol production after pentobarbitone at dioestrus-II or pro-oestrus is due to a reduction of serum LH concentrations. Pretreatment with bromocriptine delays the pentobarbitone-induced decrease. The mechanism by which bromocriptine exerts this effect is not known, but it is not due to inhibiion of serum prolactin or to an increase in serum $\mathrm{LH}$.

I thank Dr E. Flückiger of Sandoz (Basel, Switzerland) for the gift of bromocriptine; Dr F. H. de Jong (Biochemical Department) for the oestradiol and progesterone antibodies; the NIADDK for the materials used in the LH and prolactin assays; P. J. A. Woutersen for technical assistance; and Professor Dr G. H. Zeilmaker for critical comments. 


\section{References}

Ayalon, D., Tsafriri, A., Lindner, H.R., Cordova, T. \& Harell, A. (1972) Serum gonadotrophin levels in prooestrous rats in relation to the resumption of meiosis by the oocytes. J. Reprod. Fert. 31, 51-58.

Bogovich, K. \& Richards, J.R. (1982) Androgen biosynthesis in developing ovarian follicles: evidence that luteinizing hormone regulates thecal $17 \alpha$-hydroxylase and C17-20-lyase activities. Endocrinology 111, 12011208.

Braw, R.H. \& Tsafriri, A. (1980) Follicles explanted from pentobarbitone-treated rats provide a model for atresia. J. Reprod. Fert. 59, 259-265.

Butcher, R.L., Collins, W.E. \& Fugo, N.W. (1975) Altered secretion of gonadotropins and steroids resulting from delayed ovulation in the rat. Endocrinology 96, 576-586.

Clark, B.J., Scholtysik, G. \& Flückiger, E. (1978) Cardiovascular action of bromocriptine. Acta endocr., Copenh. Suppl. 216, 75-81.

Everett, J.W. \& Sawyer, C.H. (1950) A 24-hour periodicity in the "LH-release apparatus" of female rats, disclosed by barbiturate sedation. Endocrinology 47, 198-218.

Flückiger, E., Marko, M., Doepfner, W. \& Niederer, W. (1976) Effects of ergot alkaloids on the hypothalamic-pituitary axis. Postgrad. med. J. 52, 57-61.

Krishna, A., Terranova, P.F., Matteri, R.L. \& Papkoff, H. (1986) Histamine and increased ovarian blood flow mediate $\mathrm{LH}$-induced superovulation in the cyclic hamster. J. Reprod. Fert. 76, 23-29.

Nooter, K. \& Zeilmaker, G.H. (1970) Effects of ergocornine and hypothalamic stimulation on ovulation in the rat. $J$. Endocr. 48, lxiv.

Seki, M., Seki, K., Yoshihara, T., Watanabe, N., Okumura, T., Tajima, C., Huang, S.Y. \& Kuo, C.C. (1974) Direct inhibition of pituitary LH secretion in rats by CB 154 (2-Br- $\alpha$-ergocryptine). Endocrinology 94, 911-914.

Shaban, M.A. \& Terranova, P.F. (1986) 2-Bromo- $\alpha$ ergocryptine mesylate (CB-154) inhibits prolactin and luteinizing hormone secretion in the prepubertal female rat. Biol. Reprod. 34, 788-795.
Terranova, P.F. (1981) Steroidogenesis in experimentally induced atretic follicles of the hamster: a shift from estradiol to progesterone synthesis. Endocrinology 108, 1885-1890.

Terranova, P.F. \& Ascanio, L.E. (1982) Alterations of ovarian steroidogenesis induced by ovulatory delay in immature rats treated with pregnant mare serum gonadotropin. Biol. Reprod. 26, 129-139.

Tsai-Morris, C.H. \& Johnson, D.C. (1982) The steroid $17 \alpha$-hydroxylase activity of the immature rat ovary. J. Steroid Biochem. 17, 407-414.

Uilenbroek, J.Th.J. \& van der Linden, R. (1984) Effects of prolactin on follicular oestradiol production in the rat. J. Endocr. 102, 245-250.

Uilenbroek, J.Th.J., Woutersen, P.J.A. \& van der Schoot, P. (1980) Atresia of preovulatory follicles: gonadotropin binding and steroidogenic activity. Biol. Reprod. 23, 219-229.

Uilenbroek, J.Th.J., van der Linden, R. \& Woutersen, P.J.A. (1984) Changes in oestrogen biosynthesis in preovulatory rat follicles after blockage of ovulation with pentobarbitone sodium. J. Reprod. Fert. 70, 549-555.

van der Schoot, P. (1980) Delay of ovulation in rats with sodium pentobarbitone: apparent differences between rats with 4 - or 5-day reproductive cycles. $J$. Endocr. 86, 451- 457.

van der Schoot, P. \& de Greef, W.J. (1976) Dioestrous progesterone and pro-oestrous luteinizing hormone in 4 - and 5-day cycles of female rats. $J$. Endocr. 70, 61-68.

van der Schoot, P., den Besten, D. \& Uilenbroek, J.Th.J. (1982) Atresia of preovulatory follicles in rats treated with sodium pentobarbital: effects of bromocriptine. Biol. Reprod. 27, 189-199.

Wuttke, W. \& Meites, J. (1970) Effects of ether and pentobarbital on serum prolactin and LH levels in prooestrous rats. Proc. Soc. exp. Biol. Med. 135, 648-652.

Received 24 September 1988 